\title{
Fire Behaviour of Tropical and European Wood and Fire Resistance of Fire Doors Made of this Wood
}

\author{
Erich Hugi*, Empa, Swiss Federal Laboratories for Materials Science \\ and Technology, Laboratory for Building Science and Technology, \\ Empa Ueberlandstrasse 129, 8600 Duebendorf, Switzerland \\ Regina Weber, Die SchreinerZeitung, Gladbachstrasse 80, 8044 Zurich, \\ Switzerland
}

Received: 22 December 2009/Accepted: 15 December 2010/Published online: 31 December 2010

\begin{abstract}
In the building industry, there is currently a significant lack of information on fire resistance properties of room separation elements made of tropical wood species. The objective of the present study is to fill this gap by investigating the fire behaviour of tropical wood species and subsequently assessing the fire resistance of elements made of this material. In particular, the prime target was to find easy to measure parameters which correlate with both the charring rate and the deflection, the latter caused by fire induced rapid dehumidification. Further, the so found parameters have been investigated for suitability as reliable predictors for fire resistance of fire doors when tropical wood is used as substitute for European native wood. A series of measurements were carried out for tropical and European wood species. Beam deflection and charring rate as well as the fire resistance of doors were measured in standard fire (ISO 834-1). In addition, the oxygen permeability index (OPI) of wood, which appears to have a strong correlation with the charring rate, was measured. It is shown that in consideration of fire resistance both the charring rate and the deflection have to be addressed when tropical wood is used as substitute for European native wood. Finally, it is clearly confirmed that a single parameter such as wood density is not reliable to assess the substitution of an alternative wood species for a species on which fire resistance test results are available.
\end{abstract}

Keywords: Tropical wood species, Charring rate, Deflection, Fire resistance, Fire door, Substitution of wood

\section{Introduction}

In many countries such as North America, New Zealand, Scandinavian countries, Germany or Switzerland wood is used extensively for structural and room separating elements in building applications. Although sufficient native wood of good quality is available in these countries, tropical wood species are frequently imported. The Swiss State Secretariat for Economic Affairs (SECO) considers a

\footnotetext{
* Correspondence should be addressed to: Erich Hugi, E-mail: erich.hugi@empa.ch
} 
sustained fair trade with tropical wood as one opportunity to combat on-the-spot deforestation, economic deterioration and human misery [1]. In consequence, the Swiss Association of Door Manufacturers (VST), Greenpeace and World Wide Fund for Nature (WWF) Switzerland signed under the lead of SECO and the facilitation of Intercooperation an agreement which stipulates that door manufacturers strive to procure exclusively timber from sustainable managed forests [2]. In order to compensate the higher price for these materials, the procedure for the application of such wood in products with fire safety requirements had to be simplified [3]. This became necessary because an existing Swiss Standard [4], which enabled the mutual substitution of listed wood species without requiring repetition of fire resistance tests for the whole door system, was abrogated by the Swiss fire regulative board. The new regulations which refer to the harmonized European standards EN 1363-1 [5] and EN 1634-1 [6] allow any wood type that fulfils the fire resistance test, but does not allow any interchange of the wooden parts without additional costly testing. In this context, the background of this applicationoriented research was to investigate the fire behaviour of tropical wood, and more particular the resulting fire resistance of fire doors when tropical wood is used as substitute for European native wood.

In literature the charring rate is regarded as one of the most important properties with respect to the fire behaviour of wood. A comprehensive overview of performed studies during the past decades is given in [7]. Although some investigations suggest wood density, wood moisture content, air oxygen concentration, and heat flux as parameters influencing the charring rate, other studies propose easy to use functions addressing only the wood density as key parameter for an assessment of the charring rate. Eurocode 5 [8] for instance assumes that the charring rate of solid timber decreases linearly with density and remains constant for a density larger than $450 \mathrm{~kg} / \mathrm{m}^{3}$. A research study compares measured charring rates of tropical and European native wood [9] with the rates given in Eurocode 5 as well as in Australian Standard AS 1720.4 [10]. As the results do not confirm entirely adequate agreement, the authors proposed the alternative density based ULg-model to match more acceptably the acquired charring rates for wood with a density larger than $450 \mathrm{~kg} / \mathrm{m}^{3}$. From this point of view, a preliminary European standard prEN 15269-3 [11] prescribing the methodology for the interchange of wooden parts based solely on wood density has to be considered carefully especially there is no distinction of tropical and European native wood mentioned.

In contrast to load bearing heavy timber constructions [12] as Eurocode 5 actually deals with, door frames and stiffening elements of door leaves are non-loadbearing elements, have a high degree of slenderness and the fire door in its entity fulfils the integrity criteria. Because of a large surface to thickness ratio, door leaves can be regarded as a thin barrier to separate two temperature levels from each other whereas the temperature on one side of the barrier increases rapidly in accordance with a defined fire scenario. The large thermal load does not just cause a sudden ignition of all wooden parts exposed to fire, but imposes large temperature and moisture gradients perpendicular to the surface of the separating elements as well. Consequently, deflections arise which endanger the integrity of the separating element. There are only few investigations of the fire behaviour 
of fire doors performed up to now. Nevertheless, some studies showed that burning through as a failure occurs seldom compared to failures caused by the loss of integrity between door leaf and door frame [13]. In conclusion to these facts, justifying the substitution of wood species has to consider both charring rate and deflection. Focussing on the charring rate alone and in consequence using the density as a sole parameter to address the interchange of wood species may result in erroneous assessments. For this reason the prime target of the present research was to find easy to measure parameters which correlate highly with both charring rate and deflection, namely for any wood species and without exceptional cases. It is obvious that only such parameters can be used as reliable indicators for a safe assessment of mutual substitution of wood in fire doors.

One common conclusion of many investigations involving different wood species is that the charring rate is strongly affected by the wood anatomy. In consequence, the response of wood species on fire temperatures is dominantly affected by the intrinsic course of thermo-physical and thermo-chemical processes on micro scale. First understanding of this context is confirmed in [14]. To calculate the charring rate for different wood species an Arrhenius type reaction equation was formulated. In contrast, experimentally observed temperature driven moisture penetration was not discussed in depth and therefore not linked with wood anatomy. However, with respect to gas transport the wood anatomy can be easily characterized in terms of the gas permeability [15] since this particular parameter determines the rate of a fluid passing through a porous medium. Thus, the gas permeability can be considered as an appropriate parameter characterizing the charring behaviour. In addition to that, the knowledge of this parameter may also be important for the characterization of wood dehumidification on the progressive front of the pyrolysis zone. This is crucial for the development of moisture gradients [16] which cause rapid shrinkage of the material and ultimately the deflection of door leaves on macro scale.

In a first phase of this study, different parameters of wood with an assumed impact on its fire behaviour were examined on meso scale. Beam shaped specimens with similar aspect ratio as perimeter elements of door frames and door leaves were investigated regarding density, Young's modulus, oxygen permeability and moisture content. All these parameters were classified as primary parameters. Resulting from fire tests, charring rate and deflection were measured and classified as secondary parameters. In a second phase, pivoted wooden fire doors were manufactured and tested in accordance to corresponding harmonised European standard EN 1634-1. The achieved fire resistance times were analysed under consideration of the experimentally acquired primary and secondary parameters.

In summary, the result of this study has to confirm that on meso scale measured parameters capture adequately the fire induced relevant behaviour of any wood species to assess reliably the substitution of wood species in fire doors on macro scale. Virtually, the investigated fire behaviour on meso scale bridges the scale gap between processes taking place on micro scale and observable behaviour on macro scale. 


\section{Experimental}

\subsection{Investigation of Wooden Beams}

The beam shaped specimens had a length of $1 \mathrm{~m}$ with a cross section of $90 \mathrm{~mm}$ in width and $45 \mathrm{~mm}$ in height. The cross sectional dimensions correspond approximately to the size of the perimeter framing elements of door frame and door leaf having an estimated fire resistance time of $30 \mathrm{~min}$. The beams were air-dried close to equilibrium moisture content. Table 1 lists the wood species investigated. Regarding wood anatomy, rate, size and grouping of vessels are mentioned as well. In addition to tropical species, three European native wood species were investigated too. The densities of these species were within the approximate range of $400 \mathrm{~kg} / \mathrm{m}^{3}$ to $650 \mathrm{~kg} / \mathrm{m}^{3}$ which is most common for wood used in fire door applications. All the measurements were performed using three specimens of each wood species, except Abachi, Abura and Meranti Red Light. Due to shortage of availability, the latter three wood species were studied using only two specimens of each wood.

First, the Young's modulus was measured using a four point bending procedure and a Zwick 1474 test machine. These tests were performed in accordance with the European standard EN 408 [18]. The moisture content of the specimens was measured using a Bollmann H-D-3.10 moisture measuring device. For measured moisture contents in the range between $5 \%$ and $15 \%$ the relative accuracy is

\section{Table 1}

Investigated Wood Species and Their Structural Properties According to [ 17 ]

\begin{tabular}{|c|c|c|c|c|c|}
\hline Specie & Scientific name & Category & Vessel rate $(\%)$ & Vessel size & Vessel grouping \\
\hline Abachi & Triplochiton scleroxylon & Hardwood & $\approx 72$ & Large & Diffuse-porous \\
\hline Abura & $\begin{array}{l}\text { Hallea ciliate/stipulosa } \\
\quad \text { Leroy }\end{array}$ & Hardwood & $\approx 65$ & $\begin{array}{l}\text { Small to } \\
\text { medium size }\end{array}$ & Diffuse-porous \\
\hline Bibosi & Ficus glabrata & Hardwood & - & Large & Diffuse-porous \\
\hline $\begin{array}{l}\text { Cambarà } \\
\text { Rojo }\end{array}$ & Erisma spp. & Hardwood & $\approx 72$ & Very large & Diffuse-porous \\
\hline $\begin{array}{c}\text { Cambarà } \\
\text { Mixto }\end{array}$ & Erisma spp. & Hardwood & $\approx 72$ & Very large & Diffuse-porous \\
\hline Maple & Acer pseudoplatanus & Hardwood & $\approx 61$ & Very small & Diffuse-porous \\
\hline Mara Macho & $\begin{array}{l}\text { Cedrelinga } \\
\text { catenaeformis } \\
\text { Ducke }\end{array}$ & Hardwood & - & Very large & Diffuse-porous \\
\hline $\begin{array}{l}\text { Meranti } \\
\text { Red Light }\end{array}$ & $\begin{array}{l}\text { Shorea hypochra } \\
\text { Hance }\end{array}$ & Hardwood & $\approx 55$ & Very large & Diffuse-porous \\
\hline Oak & Quercus robur/petraea & Hardwood & $\approx 39$ & $\begin{array}{l}\text { Very large } \\
\text { (early w.) } \\
\text { small (late w.) }\end{array}$ & Ring-porous \\
\hline Palomaria & Calophyllum brasiliense & Hardwood & - & $\begin{array}{l}\text { Medium size } \\
\text { to large }\end{array}$ & Diffuse-porous \\
\hline Paquio & Hymenaea courbaril L. & Hardwood & $\approx 8$ & Large & Diffuse-porous \\
\hline Roble & Amburana cearensis & Hardwood & - & Large & Diffuse-porous \\
\hline Spruce & Picea abies & Softwood & - & - & No pores \\
\hline
\end{tabular}




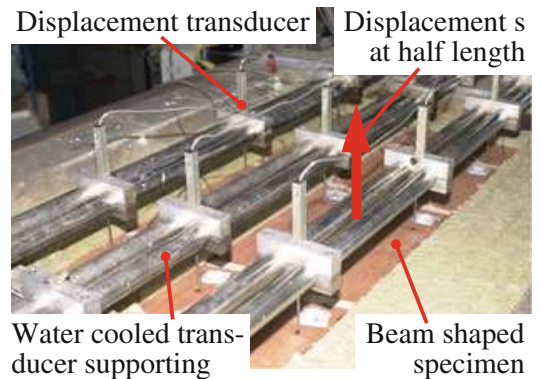

a

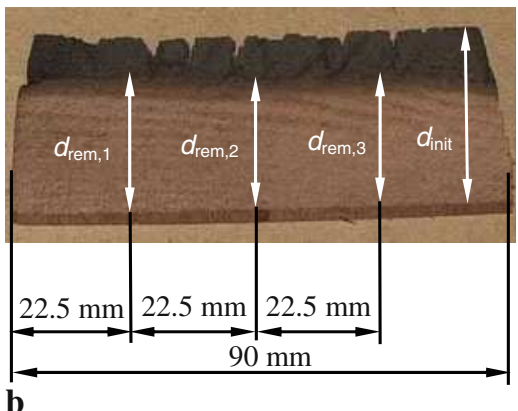

b

\section{Figure 1. Small scale horizontal furnace with three specimens sub- jected to standard fire 150 834-1 (a) and one slice out of three slices which were cut out of each specimen after subjected to standard fire for 25 min (b).}

$\pm 1.5 \%$. The measuring points were located at $5 \mathrm{~mm}$ and $15 \mathrm{~mm}$ depth on two sides of each specimen, namely positioned in centre of the $90 \mathrm{~mm}$ wide beam edge and perpendicular to this edge. The four values obtained for each beam were averaged. Each specimen was weighed and the density calculated.

In a next step, the beams were charred by using an oil-fired horizontal small scale furnace according to Figure 1a. The specimens were exposed to fire on one side according to the standardized temperature-time curve ISO 834-1 [19]. At any time after the first $10 \mathrm{~min}$ of fire exposure, the temperature recorded by any thermocouple in the furnace did not differ from the corresponding temperature of the standard temperature-time curve by more than $100^{\circ} \mathrm{C}$. The pressure inside the furnace was relative to the ambient pressure between $-5 \mathrm{~Pa}$ and $0 \mathrm{~Pa}$. The samples were arranged in a special concrete frame in which each sample was equipped with three displacement transducers on the side not exposed to fire with the purpose of measuring the deflections. After being exposed to fire for $25 \mathrm{~min}$ the samples were removed from the furnace, cooled with a water spray and cut into slices with the purpose to measure the charring rate. Subsequently, three slices of $5 \mathrm{~mm}$ thickness were cut out of each specimen, precisely at the locations where the deflection was measured during the preceding fire test. After the char layer was abraded manually using a scraper, the remaining un-charred thickness $d_{\text {rem,i }}$ was measured at three locations $i=1$ to 3 of each slice as shown in Figure 1b. In other words, the uncharred thickness $\bar{d}_{\text {rem }}$ was determined by averaging over 9 measuring points for each specimen. The charring rate, $\beta[\mathrm{mm} / \mathrm{min}]$ was calculated as follows

$$
\beta=\frac{d_{\text {init }}-\bar{d}_{r e m}}{t}
$$

where $d_{\text {init }}$ is the initial thickness [mm] of the specimen, and $t$ is the duration [min] of the test.

The deflection measurements were used to estimate the mean curvatures of each investigated beam. It was assumed that the shrinkage within the progressive front of the pyrolysis zone induces a homogeneous stress field along the beam length 
causing an elastic line which can be approximated as an ideal arc of a circle. Because the curvature is not needed for quantitative calculations but only used as a parameter making all investigated wood species comparable in terms of their deflection behaviour, this simplification is believed to be pragmatic. Therefore, the curvature, $\kappa(1 / \mathrm{m})$, was determined as follows

$$
\kappa=\frac{1}{r}=\frac{8 s}{l^{2}+4 s^{2}}
$$

where $l$ is the length (m) of the beam, $s$ the measured deflection (m) at half length of each beam as indicated in Figure 1 and $r(\mathrm{~m})$ the radius of the elastic line. The values obtained for each wood species were averaged. Accordingly, a high curvature corresponds to a large deflection.

The permeability of wood was measured at room temperature using a technique which was originally developed for concrete [20] and later adapted to wood [21]. By considering the common wood fibre orientation in perimeter elements of door frames and door leaves, only the permeability for oxygen perpendicular to the wood fibre direction was measured. Accordingly, a $25-\mathrm{mm}$ thick slice of $68-\mathrm{mm}$ diameter of wood was placed in a tight sample holder on the aperture of a closed cylinder as shown in Figure 2. Starting at ambient pressure in the closed cylinder (oxygen in this case), the pressure was increased up to $100 \mathrm{kPa}$ positive pressure. Then, the pressure decay of oxygen due to penetration into the wood slice was measured for $8 \mathrm{~h}$. The coefficient of permeability was calculated based on the pressure decay and constants that do not depend on the tested material:

$$
k=\frac{\omega \cdot V \cdot g \cdot d}{R \cdot A \cdot \theta \cdot t} \times \ln \left(\frac{P_{0}}{P(t)}\right)
$$

where $k$ is the coefficient of permeability $(\mathrm{m} / \mathrm{s}), \omega$ is the molar mass of oxygen ( $32 \mathrm{~g} / \mathrm{mol}), V$ is the volume of the pressure cylinder, $g$ the gravitational acceleration, $R$ the universal gas constant $(8.313 \mathrm{~N} \mathrm{~m} / \mathrm{K} \mathrm{mol}), A$ the sample cross section, $d$ the sample thickness, $\theta$ the absolute temperature, $t$ is time, $P_{0}$ the initial pressure in the cylinder and $P(t)$ the pressure at time $t$.

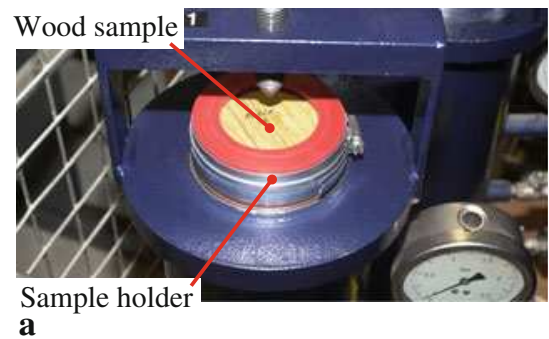

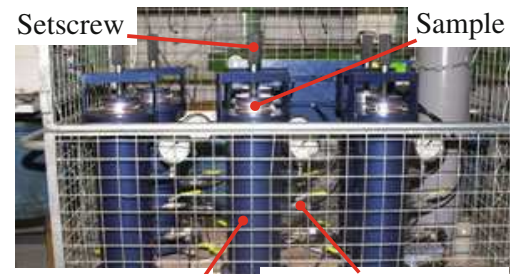

Pressure vessel $/$ Pressure transducer b

Figure 2. Oxygen permeation measurement (sample of wood placed in a tight holder (a) and positioned on the aperture of pressurised cylinders (b)). 
The oxygen permeability index (OPI) is defined as the negative logarithm of the coefficient of permeability as follows

$$
O P I=-\log _{10}(k)
$$

Accordingly, a high OPI value corresponds to low oxygen permeability and consequently to low gas permeation in general. Two measurements of the same sample of each wood species were carried out.

\subsection{Investigation of Wooden Fire Doors}

The fire experiments were carried out in accordance to the European standards EN 1363-1 and EN 1634-1 by using an oil-fired vertical large scale furnace. Temperature and pressure conditions inside the furnace were during the performed fire resistance tests fully in line with the requirements according to the standards. All investigated fire doors were mounted into a high density rigid masonry wall in such a way that the hinged door leaf was movable towards the furnace opening in each case (Figure 3a). The door opening had a height of $2.3 \mathrm{~m}$ and a width of $1.15 \mathrm{~m}$ whereas the door leaf was $47 \mathrm{~mm}$ thick. Figure $3 \mathrm{~b}$ shows a schematic vertical cut through a fire door illustrating the characteristic build-up of each tested specimen. For all constructional elements of each fire door (Figure 4), commercially available products were used. However, the structural design was chosen so
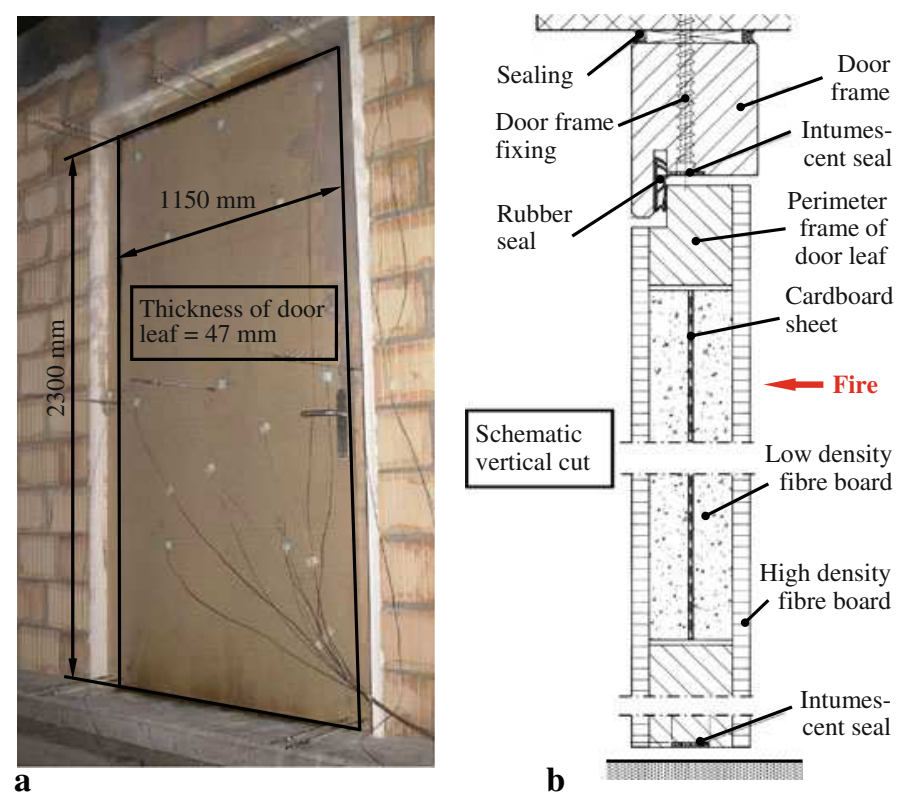

Figure 3. Large scale fire resistance test with wooden fire door subjected to the standard fire ISO $834-1$ (a) and schematic vertical cut through tested fire door (b). 


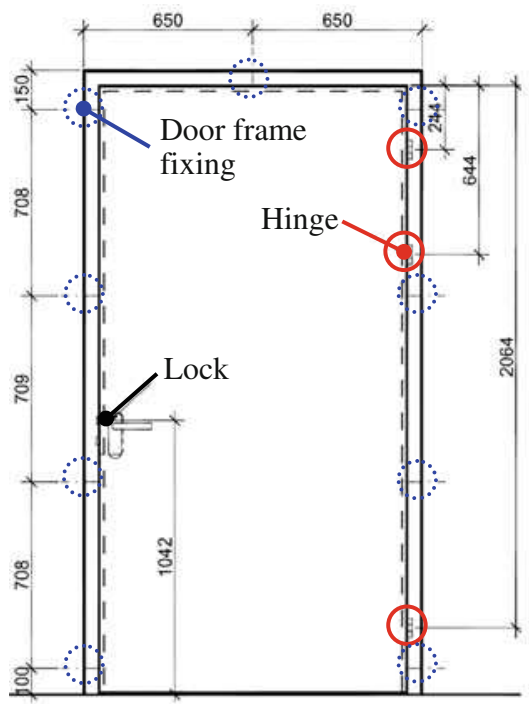

$\mathbf{a}$
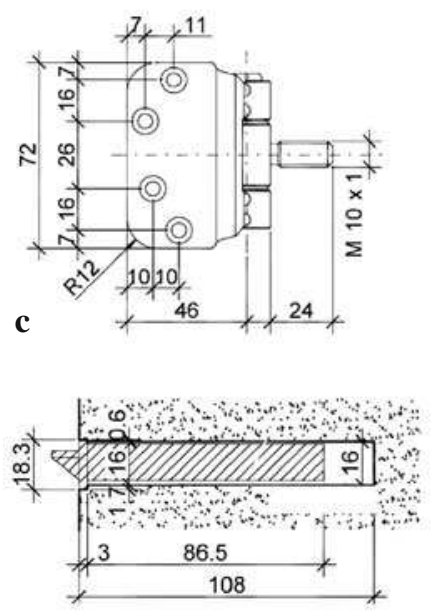

$\mathbf{e}$

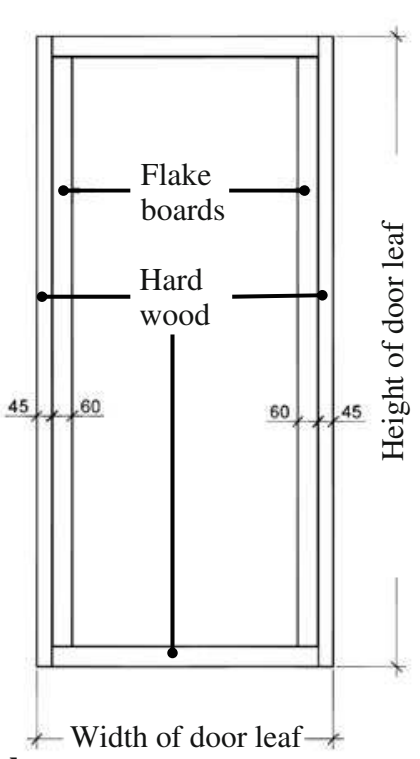

b
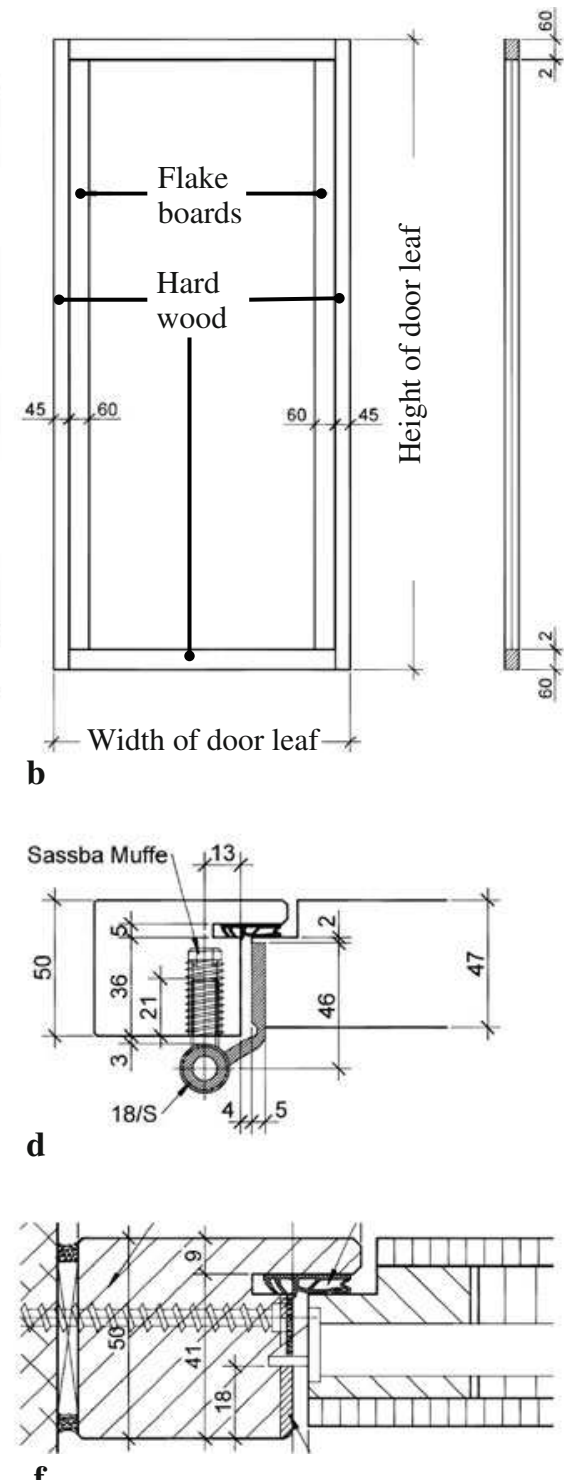

f

Figure 4. Constructional details of tested fire doors (exact location of lock, fixings and hinges (a), perimeter frame of door leaf (b), hinge (c) and hinge assembled to door leaf and door frame (d), lock (e) and lock assembled to door leaf and door frame (f)).

that the fire resistance time was affected sensitively by deflection and charring rate. Hence, only the perimeter framing elements of the door leaves and door frames were made out of the same wood as the wooden beams used for measuring primary and secondary parameters. All doors were produced by the same 
manufacturer in a single production line with a high degree of automation. By this procedure uncertainties and stochastic effects were minimised to an extent that the acquired fire resistance times were governed effectively by the variation of the applied wood species and not caused by hardly quantifiable production shortcomings. Furthermore, the connection between fire door and supporting construction was kept as simple as possible and the assembling of all tested fire doors was carried out by the same assembly operator.

\section{Results and Discussion}

\subsection{Wooden Beams}

Table 2 shows a summary of the experimentally acquired data regarding all primary and secondary parameters. The measured charring rate versus the density is shown in Figure 5. A comparison with Eurocode 5 points out that in a density range between $400 \mathrm{~kg} / \mathrm{m}^{3}$ and $700 \mathrm{~kg} / \mathrm{m}^{3}$ the recommended charring rates are smaller than the measured charring rates. This is true not only for tropical wood but also for the selected European native species. However, the calculated rates according to the Australian Standard AS 1740.4 fit appropriately the measured rates. The measured charring rate for a single wood species with a high density corresponds to the values given in [9] as well. In a density range larger than $800 \mathrm{~kg} / \mathrm{m}^{3}$ all three the Eurocode 5, the Australian Standard AS 1740.4 and the ULg-model recommend mostly conservative charring rates.

The charring rates versus the OPI values are shown in Figure 6. The values of charring rate and OPI are the mean values of the data given in Table 2 for each wood species. The resulting relation between charring rate and OPI can be represented using a linear correlation. The parameters of the correlation are given in Figure 6 as well. The acquired three set of data for density $\rho$, charring rate $\beta$ and OPI can be statistically analysed in terms of coefficient of correlation $r_{x y}$. The calculated values are $\mathrm{r}_{\rho \beta}=-0.757, \mathrm{r}_{\mathrm{OPI} \beta}=-0.801$ and $\mathrm{r}_{\rho \mathrm{OPI}}=0.669$, respectively. Considering permeability as an effective indicator for wood anatomy, the statistically confirmed relatively low correlation between wood density and OPI does not surprise. Taking into account that heat conduction and heat convection are both relevant mechanisms for heat transfer within porous media on micro scale, the better correlation between OPI and charring rate compared to the correlation between density and charring rate is in line with the theoretical conception taken as basis for this study. Despite the fact that density and OPI does not correlate well, it is astonishing that OPI correlates not outstandingly better with charring rate than density does with charring rate. This fact leads to the question which correlation may be an illusory correlation. The answer can be given by considering the following aspects: In contrast to density, which is not a reliable predictor for the anatomy of wood, charring is affected simultaneously by heat and mass transfer within the pyrolysis zone. Self-evidently, the correlation between charring rate and density turns out to be an illusory correlation because only the permeability gives an indication about the anatomy in terms of the amount of gas being able to pass through wood. The chemical analysis of produced fire gases was not 
Table 2

Beam Results for the 13 Investigated Wood Species (Primary and Secondary Parameters)

\begin{tabular}{|c|c|c|c|c|c|c|c|}
\hline Specie & $\begin{array}{l}\text { Beam } \\
\text { No. }\end{array}$ & $\begin{array}{l}\text { Density } \\
\left(\mathrm{kg} / \mathrm{m}^{3}\right)\end{array}$ & $\begin{array}{c}\text { Young's } \\
\text { modulus } \\
(\mathrm{GPa})\end{array}$ & $\begin{array}{l}\text { Charring } \\
\text { rate } \\
(\mathrm{mm} / \mathrm{min})\end{array}$ & $\begin{array}{c}\text { Curvature } \\
(1 / \mathrm{m})\end{array}$ & OPI & $\begin{array}{c}\text { Moisture } \\
\text { content }(\%)\end{array}$ \\
\hline \multirow{2}{*}{ Abachi } & 1 & 383.7 & 7.4 & 0.88 & 0.041 & 9.72 & 8.2 \\
\hline & 2 & 409.0 & 8.4 & 0.85 & 0.058 & 9.72 & 8.5 \\
\hline \multirow[t]{2}{*}{ Abura } & 1 & 558.9 & 13.5 & 0.80 & 0.054 & 10.05 & 9.2 \\
\hline & 2 & 522.0 & 11.3 & 0.89 & 0.064 & 10.05 & 8.9 \\
\hline \multirow[t]{3}{*}{ Bibosi } & 1 & 465.7 & 9.0 & 0.78 & 0.045 & 9.42 & 10.8 \\
\hline & 2 & 437.3 & 8.7 & 0.76 & 0.037 & 9.56 & 10.1 \\
\hline & 3 & 458.5 & 9.6 & 0.86 & 0.056 & - & 10.4 \\
\hline \multirow[t]{3}{*}{ Cambarà Rojo } & 1 & 604.0 & 12.4 & 0.59 & 0.017 & 10.67 & 10.3 \\
\hline & 2 & 609.1 & 12.7 & 0.61 & 0.025 & 10.77 & 9.7 \\
\hline & 3 & 597.9 & 11.3 & 0.59 & 0.012 & - & 10.0 \\
\hline \multirow[t]{3}{*}{ Cambarà Mixto } & 1 & 534.4 & 9.8 & 0.75 & 0.025 & 9.80 & 9.7 \\
\hline & 2 & 532.7 & 9.5 & 0.76 & 0.032 & 9.84 & 9.8 \\
\hline & 3 & 528.3 & 9.2 & 0.68 & 0.038 & - & 9.9 \\
\hline \multirow[t]{3}{*}{ Maple } & 1 & 624.8 & 9.5 & 0.75 & 0.222 & 9.81 & 7.4 \\
\hline & 2 & 585.0 & 9.2 & 0.82 & 0.147 & 9.82 & 6.6 \\
\hline & 3 & 538.9 & 9.5 & 0.81 & 0.095 & - & 7.3 \\
\hline \multirow[t]{3}{*}{ Mara Macho } & 1 & 613.2 & 10.2 & 0.64 & 0.016 & 10.38 & 5.8 \\
\hline & 2 & 603.4 & 10.8 & 0.62 & 0.022 & 10.70 & 6.1 \\
\hline & 3 & 590.5 & 10.6 & 0.55 & 0.021 & - & 5.7 \\
\hline \multirow[t]{2}{*}{ Meranti Red Light } & 1 & 432.1 & 12.7 & 0.68 & 0.027 & 10.60 & 8.6 \\
\hline & 2 & 438.5 & 12.6 & 0.69 & 0.035 & 10.60 & 8.6 \\
\hline \multirow[t]{3}{*}{ Oak } & 1 & 625.6 & 11.3 & 0.65 & 0.008 & 11.20 & 11.0 \\
\hline & 2 & 617.1 & 11.2 & 0.64 & 0.003 & 11.72 & 12.5 \\
\hline & 3 & 678.3 & 13.9 & 0.63 & 0.009 & - & 10.9 \\
\hline \multirow[t]{3}{*}{ Palomaria } & 1 & 609.8 & 13.5 & 0.60 & 0.050 & 10.85 & 7.4 \\
\hline & 2 & 625.5 & 12.2 & 0.58 & 0.039 & 11.04 & 7.7 \\
\hline & 3 & 598.4 & 11.4 & 0.62 & 0.018 & - & 7.6 \\
\hline Paquio $^{\mathrm{a}}$ & 1 & 1025.4 & - & 0.38 & 0.155 & 11.15 & 12.0 \\
\hline \multirow[t]{3}{*}{ Roble } & 1 & 698.3 & 10.0 & 0.50 & 0.164 & 10.78 & 7.9 \\
\hline & 2 & 674.1 & 12.3 & 0.53 & 0.143 & 10.95 & 9.8 \\
\hline & 3 & 653.8 & 11.7 & 0.53 & 0.113 & - & 8.5 \\
\hline \multirow[t]{3}{*}{ Spruce } & 1 & 421.3 & 11.3 & 0.71 & 0.029 & 10.37 & 9.3 \\
\hline & 2 & 405.8 & 10.9 & 0.73 & 0.021 & 10.45 & 10.1 \\
\hline & 3 & 408.2 & 9.8 & 0.73 & 0.016 & - & 8.4 \\
\hline
\end{tabular}

\footnotetext{
${ }^{\text {a }}$ For comparison reasons, a wood specie having a significantly larger density as commonly applied in fire doors
} $\left(400 \mathrm{~kg} / \mathrm{m}^{3}\right.$ to $\left.650 \mathrm{~kg} / \mathrm{m}^{3}\right)$ was investigated as well

part of this study. However, it is known that charring is also essentially affected by the composition of the fire gases with respect to chemical degradation of the wood cell structure within the pyrolysis zone [22]. Also from this point of view it becomes obvious that a pronounced permeation of chemically reactive fire gases accelerates the cell wall degradation and hence an acceleration of the macroscopically observable charring rate as well. 


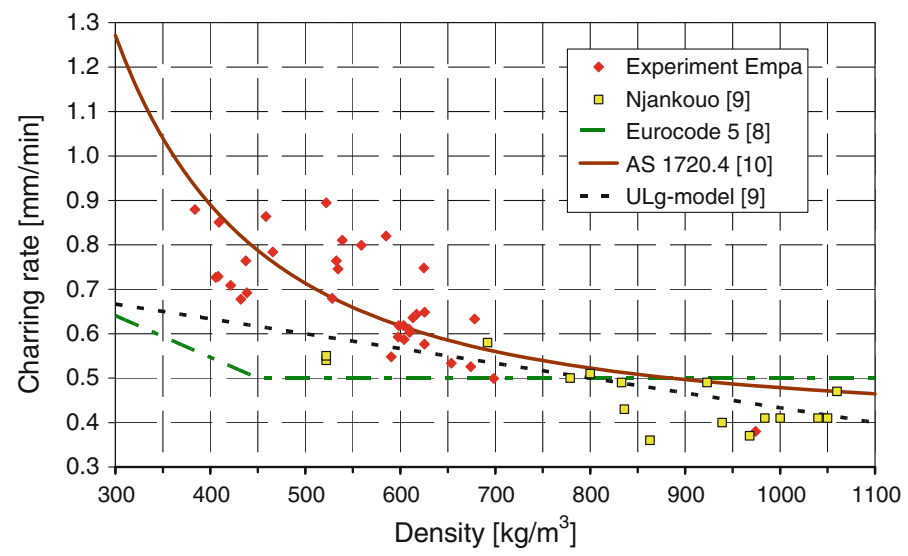

Figure 5. Measured charring rate versus density and comparison with various recommendations.

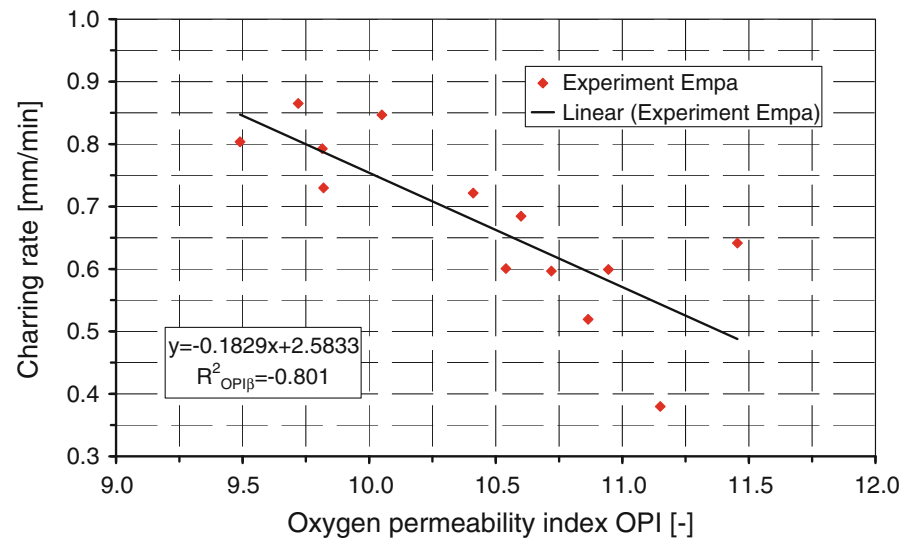

\section{Figure 6. Measured charring rate versus OPI and corresponding linear regression analysis.}

Differences between the charring rates in accordance with the recommendations given in [8-10] and the corresponding measured charring rates were also calculated and subsequently analysed statistically. Table 3 shows the results referring to the estimation of mean value $\mu$ and standard deviation $\sigma$. Whereas Eurocode 5 estimates too low charring rates within a density range from $400 \mathrm{~kg} / \mathrm{m}^{3}$ to $700 \mathrm{~kg} / \mathrm{m}^{3}$, Australian Standard AS 1720.4 gives adequate agreement between measurement and calculation within the same density range. However, good agreement of density and charring rate has to be addressed carefully and is limited in terms of effectively investigated wood species and covered density range. Finally, no seriously satisfying correlation was found between any of the investigated primary parameters and the curvature as a secondary parameter. This result implies that hardly another single primary parameter exists to capture the complex 
Table 3

Estimation of Mean Value $\mu$ and Standard Deviation $\sigma$ of the Differences Between Measured and Recommended Charring Rates (It is Assumed that the Differences are Subjected to a Gaussian Distribution)

\begin{tabular}{lcc}
\hline Recommendation & Mean value $\mu(\mathrm{mm} / \mathrm{min})$ & Standard deviation $\sigma(\mathrm{mm} / \mathrm{min})$ \\
\hline Linear correlation $^{\mathrm{a}}$ & 0.00 & 0.083 \\
AS 1720.4 [10] & 0.00 & 0.095 \\
ULg-model [9] & -0.10 & 0.094 \\
Eurocode 5 [8] & -0.17 & 0.115 \\
\hline
\end{tabular}

${ }^{\text {a }}$ Calculation of charring rate is in line with the linear regression analysis according to Figure 6

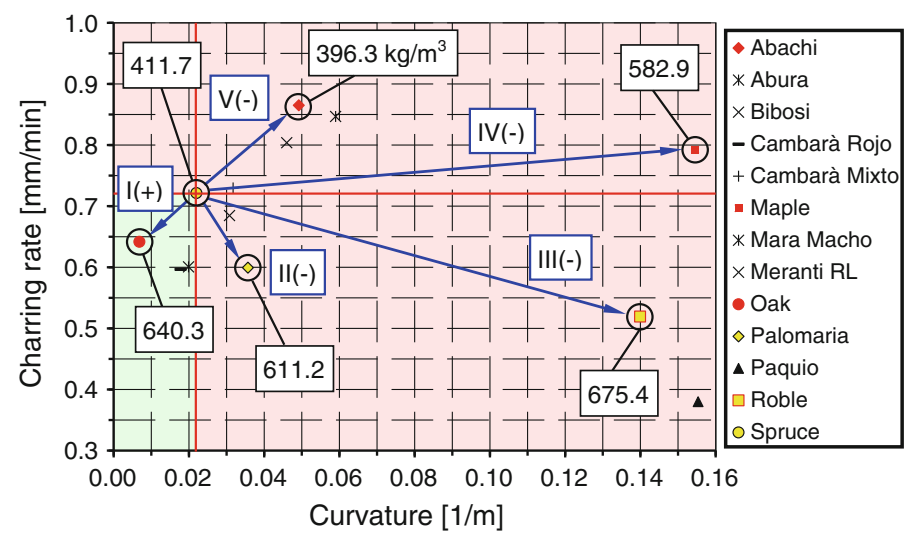

Figure 7. Measured charring rate versus beam curvature and highlighted areas for reliable (lower left quadrant with Spruce as reference) and not reliable (lower right, upper left and upper right quadrants with Spruce as reference) types of substitutions of Oak (substifution I), Palomaria (II), Roble (III), Maple (IV), Abachi (V) for the reference wood species Spruce.

mechanisms on micro scale to predict adequately the intrinsic deflection behaviour of any wood species. In consequence, the assessment of the substitution of an alternative wood species for a species on which fire resistance test results are available can also not be done based purely on a sole parameter. But this presumption needs to be validated under consideration of the experimental data acquired on macro scale. However, Figure 7 shows the charring rates of all wood samples versus the curvature values. Because both charring rate and curvature go hand in hand as relevant parameters affecting the behaviour of a door in case of fire, the selection of wood species applied in subsequent large scale testing had been made on the basis of this figure. The hypothetical scenario was like that: A fire door with perimeter framing elements made of Spruce was tested in line with EN 1363-1 and EN 1634-1. Now an alternative wood species is substituted for Spruce 
under the requirement that the fire resistance is at least as long as it was for Spruce. Compared to all other investigated wood species, Oak had the smallest curvature and a small charring rate as well. In contrast, the Maple beams displayed the largest curvatures of all investigated wood species and also its charring rate was nearly highest. Compared to Maple, the Roble beams showed similar curvatures but significantly smaller charring rates. Again with respect to Maple, Abachi behaved differently from Roble: Charring rate of Abachi was very similar to Maple but the curvature turned out to be significantly smaller. The selection of the species for fire tests on macro scale was based on the following ideas: Compared to Spruce, a larger curvature and/or a larger charring rate should effect a reduction of fire resistance. Again compared to Spruce and in terms of fire resistance, a larger charring rate can be eventually compensated by a smaller curvature and vice versa. Therefore, Palomaria has been additionally chosen because both charring rate and curvature deviated only moderately from the values performed by Spruce. In summary, only wood species with fire behaviour of smaller charring rate and smaller curvature than Spruce (lower left quadrant of Figure 7 with Spruce as reference) are suitable as substitute for Spruce. In consequence, substitution I (Spruce replaced with Oak) is flagged with “+”. All other substitutions II to V are flagged with "-,".

\subsection{Wooden Fire Doors}

Seven fire experiments with doors were carried out. The progression of all fire tests had equal characteristics as shown in Figure 8. From the beginning all door leaves deflected concavely away from the fire side primarily caused by the shrinkage of the ignited high density fibre board on fire side. In detail, the upper unsupported door leaf corner on the lock set side moved towards the fire (Figure 8a). As a consequence the relative overlap within the rebate formed by the perimeter framing elements of door frame and door leaf was reduced continuously. The maximum deflection with respect to reduction of overlap occurred always at the upper unsupported corner of the door. Later the door leaf sagged (Figure 8b) and accordingly the rebate height increased along the upper edge of the door leaf. In the further course of the test the intumescent seal was not able to seal entirely the growing gap at the upper unsupported corner and glowing occurred partially (Figure 8c). Finally, the failure mode was identical for all investigated fire doors: Loss of integrity due to sustained penetration of flames at the upper door edge (Figure 8d). All fire tests were stopped immediately when integrity was not fulfilled anymore. Table 4 gives a complete survey of all conducted fire experiments.

Figure 9 summarises the deflection of the upper unsupported door leaf corner on lock set side as a function of time. Maximum deflection of each door and its failure occurred simultaneously. The door set made of Oak was tested twice to get a better understanding of the reproducibility of the achieved fire resistance time. The two failures occurred within a narrow period of time which duration was only $6 \mathrm{~s}$. This result allows the assumption that the individually measured failure times of all additionally tested doors are in fact representative for the door system. Figure 9 confirms a reduction of deflection approximately between the 6 th 


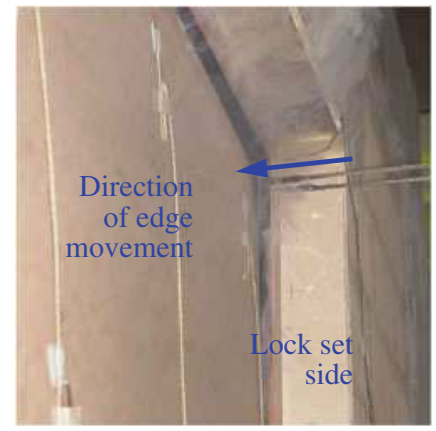

$\mathbf{a}$

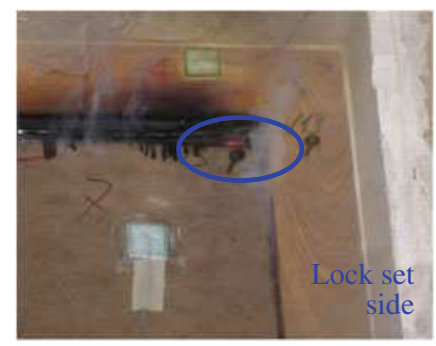

c

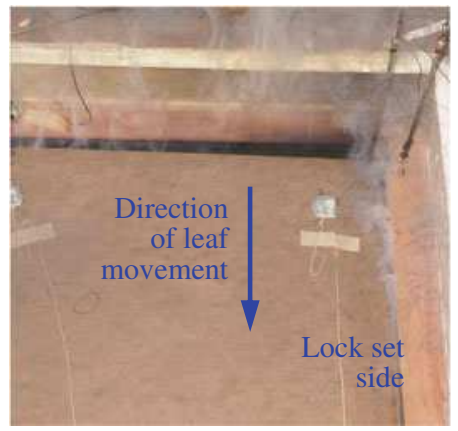

b

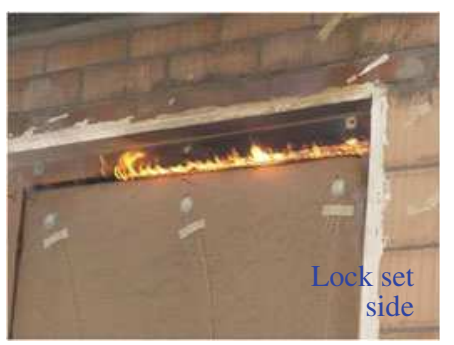

d

Figure 8. Representative course from starting the fire test till interruption due to loss of integrity (flame penetration, steps (a)-(d) represent increasing time during fire experiment). (a) Reduction of overlap, (b) sagging of door leaf, (c) occurrence of glowing, and (d) loss of infegrity.

\section{Table 4}

Point in Time of Distinctive Observations which are Relevant for Loss of Integrity

\begin{tabular}{|c|c|c|c|c|c|}
\hline $\begin{array}{l}\text { Wood } \\
\text { type }\end{array}$ & $\begin{array}{c}\text { Lowering } \\
\text { entire door } \\
\text { leaf }{ }^{\mathrm{a}}(\mathrm{min} \text { and } \mathrm{s})\end{array}$ & $\begin{array}{l}\text { Occurrence } \\
\text { of glowing } \\
\text { (min and } \mathrm{s} \text { ) }\end{array}$ & $\begin{array}{c}\text { Reduction of } \\
\text { re-bate after } \\
5 \mathrm{~min}(\mathrm{~mm}) /(\%)^{\mathrm{b}, \mathrm{c}}\end{array}$ & $\begin{array}{c}\text { Reduction of } \\
\text { re-bate after } \\
15 \min (\mathrm{mm}) /(\%)^{\mathrm{b}, \mathrm{c}}\end{array}$ & $\begin{array}{c}\text { Loss of } \\
\text { integrity }{ }^{\mathrm{b}, \mathrm{d}} \\
\text { (min and } \mathrm{s})\end{array}$ \\
\hline Oak 1 & $8^{\prime} 30^{\prime \prime}$ & $27^{\prime} 25^{\prime \prime}$ & $4 / 14$ & $5 / 17$ & $28^{\prime} 04^{\prime \prime}$ \\
\hline Oak 2 & $7^{\prime} 26^{\prime \prime}$ & $25^{\prime} 30^{\prime \prime}$ & $6 / 21$ & $6 / 21$ & $27^{\prime} 58^{\prime \prime}$ \\
\hline Abachi & $5^{\prime} 00^{\prime \prime}$ & $9^{\prime} 40^{\prime \prime}$ & $15 / 52$ & - & $9^{\prime} 45^{\prime \prime}$ \\
\hline Maple & $7^{\prime} 30^{\prime \prime}$ & $12^{\prime} 50^{\prime \prime}$ & $7 / 24$ & $11 / 38$ & $17^{\prime} 30^{\prime \prime}$ \\
\hline Palomaria & $4^{\prime} 50^{\prime \prime}$ & $17^{\prime} 30^{\prime \prime}$ & $7 / 24$ & $23 / 79$ & $18^{\prime} 51^{\prime \prime}$ \\
\hline Roble & $5^{\prime} 30^{\prime \prime}$ & $21^{\prime} 00^{\prime \prime}$ & $8 / 28$ & $14 / 48$ & $23^{\prime} 00^{\prime \prime}$ \\
\hline Spruce & $6^{\prime} 16^{\prime \prime}$ & $22^{\prime} 50^{\prime \prime}$ & $6 / 21$ & $9 / 31$ & $24^{\prime} 30^{\prime \prime}$ \\
\hline
\end{tabular}

\footnotetext{
${ }^{a}$ Induced by the reduction of mechanical linkage between leaf and frame due to charring

${ }^{\mathrm{b}}$ Located at the upper door edge on lock set side

${ }^{c}$ Reduction in $\mathrm{mm}$ and in $\%$ of the initial rebate at the beginning of fire experiment

${ }^{\mathrm{d}}$ Sustained flame penetration
} 


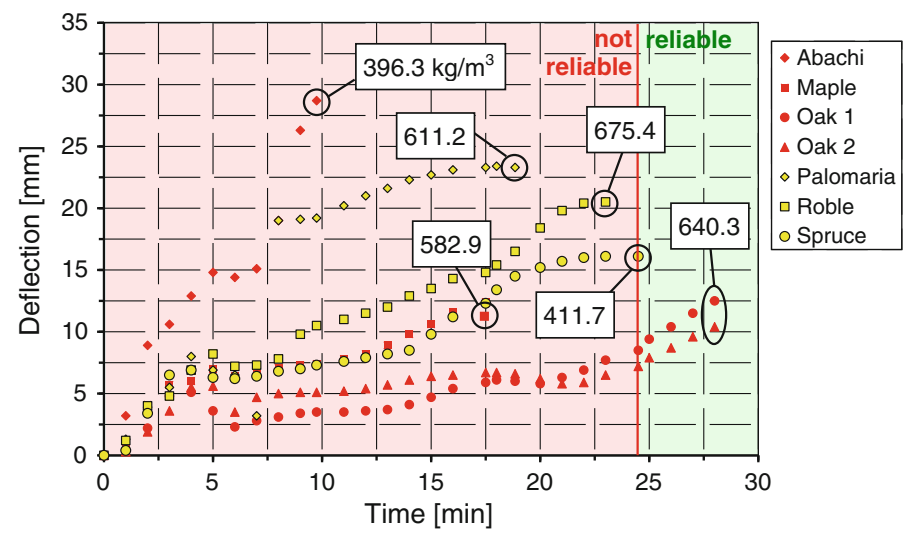

\section{Figure 9. Deflection towards fire of upper unsupported door leaf corner on lock side as function of time (exposition of deflection ends at time when loss of integrity occurred).}

and 8th minute for all tested specimens. This behaviour is related to the fire exposed high density fibre board which always ignited approximately $1.5 \mathrm{~min}$ after the fire experiments started. The shrinkage of these boards due to the loss of moisture induced the observed first phase of fast increasing deflection. With rising furnace temperature the composite action of the burning high density fibre board and the perimeter framing elements of the door leaf became weaker. As a result the board induced deflection was not transmitted further in full strength from the fibre board to the perimeter frame of the door leaf and accordingly deflection started to stagnate or even became smaller. Hence, after the 8 th minute the increasing deflections were affected dominantly by the chosen wood type of the perimeter frame of door leaves and not anymore by the high density fibre board.

Compared to Spruce, Figure 9 confirms only for Oak a longer fire resistance time. With respect to the indicated densities it becomes obvious that not the wood species with the highest density achieved the longest fire resistance time. For instance Roble with a density of $675.4 \mathrm{~kg} / \mathrm{m}^{3}$ displayed a fire resistance time which was nearly $20 \%$ shorter than the resistance time of Oak with a density of only $640.3 \mathrm{~kg} / \mathrm{m}^{3}$. By keeping the lifelike variation of wood density in mind, Oak, Palomaria and Maple are treated in practise most probably as wood of same density. Under consideration of prEN 15269-3, Oak can be replaced by both Palomaria and Maple without additional testing. The same is true when Roble, Palomaria and Maple are substituted for Spruce. This is in contrast to the test results that confirmed for instance for Maple a fire resistance time which was nearly 30\% shorter than the resistance time of Spruce. Finally, Abachi having the lowest density of all tested wood types achieved ultimately the shortest resistance time.

Figure 10 validates the assumption that only wood species with smaller charring rate and smaller curvature are suitable for replacing Spruce. The five substitutions, actually Oak (I), Palomaria (II), Roble (III), Maple (IV) and Abachi (V) for Spruce, are assessed by taking into account all investigated primary parameters 


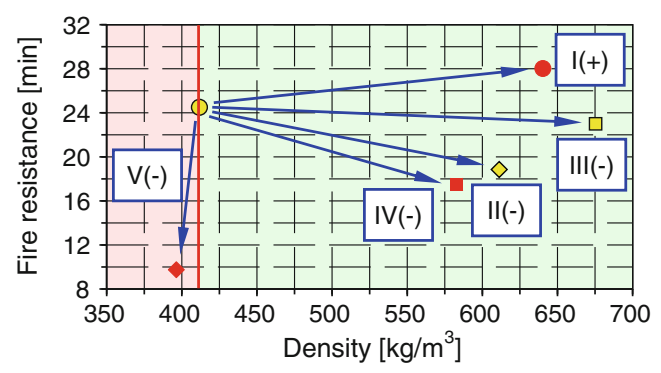

a

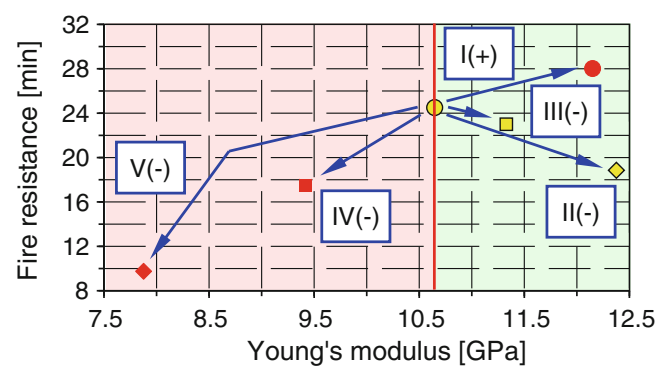

b

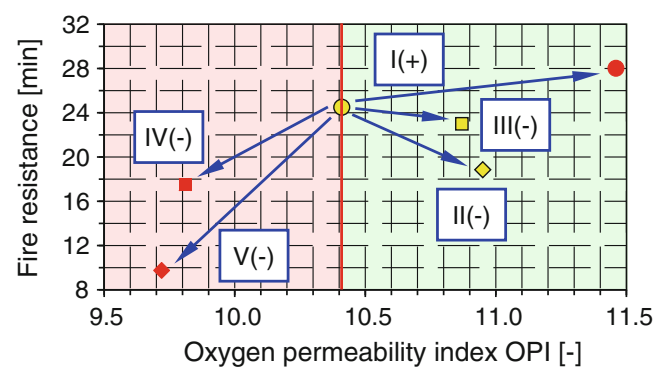

c

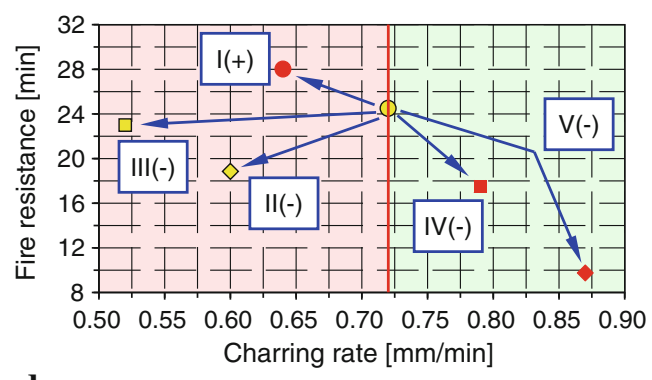

d

Figure 10. Assessment of the substitutions Oak (I), Palomaria (II), Roble (III), Maple (IV) and Abachi (V) for Spruce based on primary and secondary parameters. (a) Substifution based on density, (b) substitution based on Young's modulus, (c) substifution based on OPI, and (d) substitution based on charring rate. 
and charring rate as a secondary parameter. In all cases, at least two of the five substitutions result in a wrong expectation of fire resistance compared to the fire resistance which was achieved with Spruce. Astonishingly, the commonly promoted substitution based on density achieves the worst result: Three of five substitutions $(60 \%)$ are erroneous. This is in contrast with the assessment of the substitution that uses both secondary parameters.

Obviously an interchange of wood without additional large scale testing is only reliable in terms of fire resistance when the secondary parameters charring rate and curvature of alternative wood species are effectively smaller than the ones of the original wood. Hence, it becomes obvious that the assessment of the substitution of wood based on the secondary parameters is more reliable than the assessment done solely with regard to the wood density. Under consideration of Figure 7 it was expected that the fire door made of Palomaria would perform a fire resistance time similar to the one of Oak. Surprisingly, the resistance time turned out to be significantly smaller and even smaller than performed by Roble. Post fire investigation addressing the mechanical linkage between the perimeter framing elements of door frame and door leaf resulted in the following picture: Although the charring rate of Palomaria did not differ much from the charring rate of Oak the fixing of lock set and hinges was more severely damaged by the fire in case of Palomaria (Figure 11). Accordingly, the screws were hardly able to keep neither the lock set nor the hinges in position and right after switching off the furnace burners the door leaf made of Palomaria fell off the frame (Figure 11a). In contrast, all mechanical linkages in case of Oak were in good condition after stopping the fire test (Figure 11b). Consequently, the resistance against pulling out of fixing elements has to be considered carefully as well when European native wood species are replaced by tropical wood species. It was not part of this study to investigate this specific aspect more deeply. However, it has to be kept in mind that for European wood species the growth rings are strictly correlated with the yearly temperature oscillations, whereas in tropical areas the growth increments may reflect alternating wet and dry seasons.

\section{Conclusion}

The fire resistance of fire doors is highly affected by both the charring rate of the applied wood species and the door leaf deflection both causing a reduction of the overlap within the rebate at the upper unsupported door leaf corner. Regarding the assessment of a possible substitution of a certain wood species by another species, charring rate and deflection have to be considered in depth.

An explicit correlation between the charring rate and the oxygen permeability index OPI was found. However, regarding the results of a series of fire experiments using wooden beams, no correlation was found between the observed curvature of the beams and the investigated primary parameters such as density, Young's modulus, OPI, etc. Thus, the fire resistance of a fire door can not be predicted satisfactorily by using only one single parameter. In consequence, the proposal of prEN15269-3 to assess the substitution of wood just on the basis of wood 


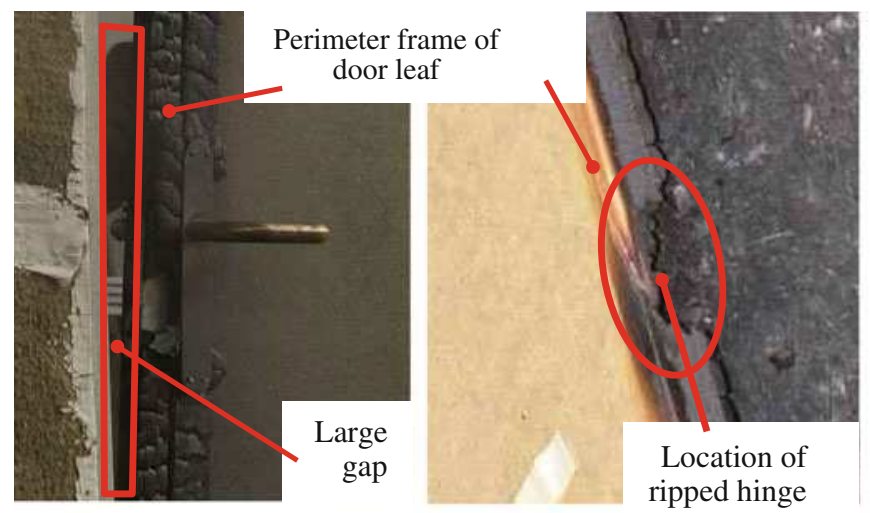

a

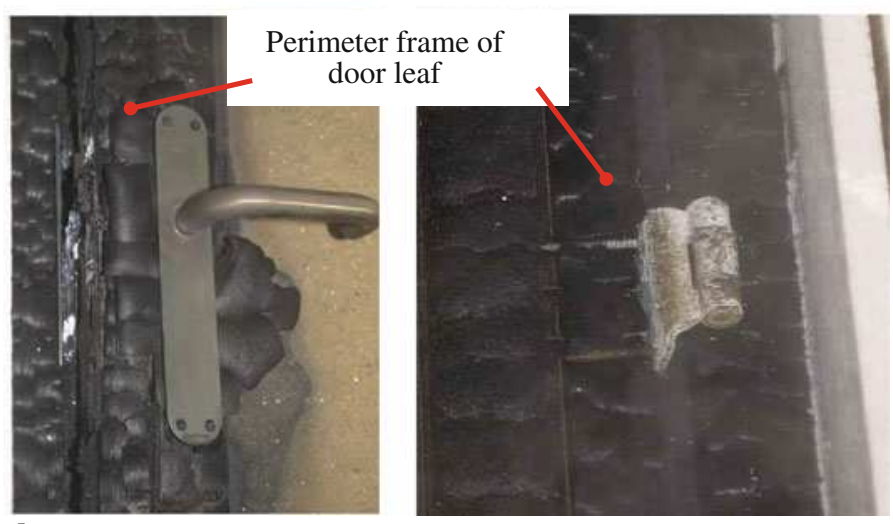

b

\section{Figure 11. Comparison of lock set and upper hinge area for two} fire doors made of different wood species. (a) Fire door made of Palomaria and (b) fire door made of Oak.

density has to be reconsidered very carefully. This applies not just in case of the substitution of European native wood by tropical wood but also for the interchange of European native wood species among each other.

It is clear that the performance of fire doors is influenced strongly by their constructive design. However, the acquired experimental results show without any doubt that for a given fire door design the interchange of wood is safe if beams made of the alternative wood perform smaller charring rate and smaller curvature. In consequence, it turned out that the anatomy of wood species, which is most relevant for thermo-physical and thermo-chemical processes on micro scale, can be appropriately captured by cost-efficient fire experiments on meso scale. Other primary parameters measured under conditions without any similarity to fire conditions are obviously not suitable to bridge the scale factor form micro scale to macro scale.

In all other cases the usability of an alternative wood has to be proved in an additional large scale experiment. This is because the question to which extent a 
lower charring rate compensates an increased curvature and vice versa remains unanswered. Finally, the statistical assessment of the experimentally acquired data gives no correlation neither between density and charring rate nor density and deflection. Consequently, relaying solely on density for the judgment of the interchange of wood leads to products which have in their end use application significantly shorter fire resistance times.

\section{Acknowledgments}

The authors express their gratitude to K. Schmidt (Intercooperation-Swiss Foundation for Development and International Cooperation), B. Müller (passed away in 2007) (Müller Consulting) and N. Knecht (Theodor Nagel GmbH) for their huge engagement to organise all tropical wood species and to bring the wood safely from South America to Switzerland; A. Demont, M. Meier and R. Ganz (members of the Empa fire laboratory staff) for assistance in preparing and executing the fire tests; P. Janutin (RWD Schlatter AG) for supervising the manufacturing of all fire doors of high quality and consistency; R. Herzig (former director of VST) for initiating and supporting the project. This study has been funded by State Secretariat for Economic Affairs SECO, Swiss Association of Door Manufacturers VST and Empa.

\section{References}

1. State Secretariat for Economic Affairs (SECO) (2007) Sustainable trade with tropical wood: fighting poverty and preservation of tropical forest; in German

2. Swiss Foundation for Development and International Cooperation IC (2004) Agreement between the Swiss Association of Door Manufacturers (VST), Greenpeace Switzerland and World Wide Fund for Nature (WWF) Switzerland concerning the procuring of timber and timber products; in German

3. Swiss Foundation for Development and International Cooperation IC (2004) Action plan of the agreement between the Swiss Association of Door Manufacturers (VST), Greenpeace Switzerland and World Wide Fund for Nature (WWF) Switzerland concerning the procuring of timber and timber products; in German

4. SIA/Lignum (1997) Fire safety for multi story buildings. SIA Documentation 83, Zurich; in German

5. European Standard EN 1363-1 (1999) Fire resistance tests. Part 1. General requirements

6. European Standard EN 1634-1 (2008) Fire resistance and smoke control tests for door, shutter and openable window assemblies and elements of building hardware. Part 1. Fire resistance tests for doors, shutters and openable windows

7. Babrauskas V (2005) Charring rate of wood as a tool for fire investigations. Fire Saf $\mathbf{J}$ 40:528-554

8. European Standard EN 1995-1-2: 2004 + AC (2006) Eurocode 5: design of timber structures. Part 1-2. General-structural fire design 
9. Njankouo JM, Dotreppe JC, Franssen JM (2005) Fire resistance of timbers from tropical countries and comparison of experimental charring rates with various models. Construct Build Mater 19:376-386

10. Australian Standard AS 1720.4 (2006) Timber structures. Part 4. Fire resistance for structural adequacy of timber members. Standards Australia, North Sydney, Australia

11. European Standard prEN 15269-3 (2008) Extended application of test results for fire resistance and/or smoke control for door, shutter and openable window assemblies, including their elements of building hardware. Part 3. Fire resistance of hinged and pivoted timber doorsets and openable timber framed windows

12. Buchanan AH (2001) Structural design for fire safety. Wiley, p 273

13. Eickner HW (1973) Fire resistance of solid-core wood flush doors. For Prod J 23:38-43

14. Schaffer EL (1967) Charring rate of selected woods-transverse to grain. U.S. Forest Service Research Paper FPL 69, pp 1-22

15. Resch H, Ecklund BA (1964) Permeability of wood. For Prod J May:199-206

16. White RH, Schaffer EL (1981) Transient moisture gradient in fire-exposed wood slab. Wood Fibre 13(1):17-38

17. Wagenführ R (2007) Holzatlas. Fachbuchverlag Leipzig im Carl Hanser Verlag, p 816

18. European Standard EN 408 (2003) Timber structures - structural timber and glued laminated timber - determination of some physical and mechanical properties

19. International standard ISO 834-1 (1999) Fire-resistance tests - elements of building construction. Part 1. General requirements. International Organization for Standardization, Geneva

20. Beushausen HD, Alexander MG, Mackechnie J (2003) Concrete durability specifications in an international context. BFT Concrete. Plant Precast Technol 7:22-32

21. Hugi E, Wuersch M, Risi W, Ghazi Wakili K (2007) Correlation between charring rate and oxygen permeability for 12 different wood species. J Wood Sci 53:71-75

22. Lingens A, Windeisen E, Wegener G (2005) Investigating the combustion behaviour of various wood species via their fire gases. Wood Sci Technol 39:49-61 